CEP Discussion Paper No 676

February 2005

\title{
Catching a Wave: the Adoption of Voice and High- Commitment Workplace Practices in Britain, 1984-1998
}

Alex Bryson, Rafael Gomez and Tobias Kretschmer

The Leverhulme Trust

Registered Charity No: 288371

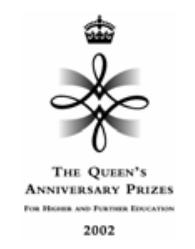




\begin{abstract}
In this paper we treat workplace voice and systems of high-commitment human resource management (HCHRM) as technological innovations in order to account for the uneven diffusion patterns observed across establishments. Using British data, the paper finds that variables highlighted in the technological diffusion literature are significant predictors of voice and HRM adoption decisions. Workplace size, size of multi-establishment network, ownership type, set-up date and network affects all play a significant role in high-commitment HRM adoption. We also find that union presence, per se, is not an inhibitor to the adoption of high commitment HRM practices.
\end{abstract}

Keywords: High-commitment work practices, voice, unions, technology diffusion, complementarities

JEL Classifications: J51, M54, O33

The Centre for Economic Performance is financed by the Economic and Social Research Council.

\title{
Acknowledgements
}

This paper is produced under the 'Future of Trade Unions in Modern Britain' Programme supported by the Leverhulme Trust. The Centre for Economic Performance acknowledges with thanks, the generosity of the Trust. For more information concerning this Programme please e-mail future of unions@1se.ac.u

Alex Bryson is Principal Research Fellow at the Policy Studies Institute, London. Email: a.bryson@psi.org.uk Rafael Gomez and Tobias Kretschmer are Lecturers in the Interdisciplinary Institute of Management, LSE. Email: r.gomez@1se.ac.uk; t.kretschmer@1se.ac.uk Tobias Kretschmer, Alex Bryson and Rafael Gomez are all Research Associates for the Future of Unions in Modern Britain Research Group, Centre for Economic Performance, LSE.

Published by

Centre for Economic Performance

London School of Economics and Political Science

Houghton Street

London WC2A $2 \mathrm{AE}$

All rights reserved. No part of this publication may be reproduced, stored in a retrieval system or transmitted in any form or by any means without the prior permission in writing of the publisher nor be issued to the public or circulated in any form other than that in which it is published.

Requests for permission to reproduce any article or part of the Working Paper should be sent to the editor at the above address.

(C) A. Bryson, R. Gomez and T. Kretschmer, submitted 2005

ISBN 0753018160 


\section{$\underline{1 . \text { Introduction }}$}

From administering payroll to the provision of meaningful two-way forms of workplace communication, the management of human resources occurs across a number of dimensions. When employers treat these latter dimensions seriously, they can be said to employ a formal voice regime at their workplace Voice regimes can be direct or representative in nature and can be delivered in a number of ways; via a union, through management led initiatives or as part of some dual channel where management voice and union collective representation are both present (Willman et al., 2004). Voice can also be accompanied by a system of high commitment human resource management $(\mathrm{HCHRM})$ practices. The specific practices that form part of any given HCHRM system can be quite diverse, but typically they involve managerial attempts to motivate and manage workers through a series of workplace practices rather than through strict command and control structures. These various choices (e.g., the choice between adopting certain HCHRM practices or not, between offering voice or not, and between the in-house employer provision of voice or some union provision of voice) can be thought of as "technological" or "process innovation" adoption decisions. In this paper we model the correlates of these adoption decisions for British workplaces.

The impetus for this paper stems from a basic problem noted by a number of previous researchers (Erikson and Jacoby 2003; Baker, 1999) - voice and HCHRM have been found to impart measurable benefits to adopting firms, yet ubiquitous adoption has not occurred (Ichniowski et al., 1996; Godard 2004). Up to now, most explanations for uneven diffusion patterns have relied on fairly ad hoc model specifications and apart from some recent exceptions (Eriksson, 2002), most of the literature has focused almost exclusively on the US.

In this paper we treat voice and HCHRM as technological innovations and explain why this approach can help explain the adoption patterns of British establishments over time. Specifically, we use Workplace Employment Relations Survey (WERS) data from 1984 to 1998 to answer a series of longstanding questions in the HCHRM literature. We begin by asking 
whether the presence of voice is a significant predictor of HCHRM intensity. The existence of a positive correlation between the two usage decisions would be an indicator of "supermodularity" (Milgrom and Roberts, 1995). As a corollary we also ask which voice-type (i.e., union, dual or non-union) is most strongly linked to HCHRM intensity. This is an important question as it has been argued that HCHRM and union voice act as substitutes at the workplace. We then ask what workplace characteristics are likely to increase the net benefit of adopting voice and HCHRM and test whether these associations are empirically significant. Finally, we ask why it is that sector (state sector vs. private sector) and ownership type (family owned vs. publicly owned) remain such significant predictors of voice and HCHRM intensity across workplaces, even after controlling for typical explanations such as workplace size and industry.

We begin by looking at the formal literature on technological diffusion and develop hypotheses regarding the effect of several key variables on the adoption of voice and highcommitment human resource innovations at the workplace. Next we look at the data and describe the pattern of voice and HCHRM adoption in Britain. Then we test the hypotheses developed earlier using establishment data on variables linked to several diffusion models. We do this so as to distinguish which model is at work. We end with a discussion of the implications of our work for both theory and practice.

\section{Theoretical Background}

Implementing high-commitment human resource practices such as self-directed work teams or the adoption of a grievance procedure for employees seems straightforward: if the HRM practice or voice regime provides a net benefit (i.e. the discounted sum of future benefits less the cost of implementing the practice) it should be adopted by the workplace. In particular, it would seem that a practice (or set of practices) that conveys net benefits such as increased motivation, lower turnover, and greater information sharing should be adopted ubiquitously across all establishments. As can be seen from Figures 1 and 2, however, the distribution of voice (i.e., the 
presence of some formal two-way form of communication) and high-commitment HRM practices across British establishments is not uniform. The HR practices that we consider high-commitment are 13 in total and are derived from studies by Pfeffer (1995) and Storey (1992). The specific measures are discussed in detail in section 3 of the paper, but what is of importance in this context is that looking at the empirical distribution of HRM practices (figure 1) in 1998, we find that 27.7 percent of establishments with more than 10 employees had implemented fewer than 4 HRM practices, while an almost equal proportion had employed more than 10. Clearly, ubiquitous adoption has not occurred and there is substantial variation in HCHRM intensity that requires explaining.

In the case of voice, adoption varies considerably by firm characteristics such as set-up date and sector (figure 2). This seems to suggest that there are more differentiated considerations at play than the simple cost-benefit model would suggest. In particular, we have to ask what it is that keeps workplaces from implementing better (more profitable) HRM and voice-related practices? ${ }_{1}$ A look at the concepts of adoption and diffusion of new technologies may be helpful here.

\subsection{High-Commitment HRM and Voice as a Problem of Technology Adoption}

In what way, then, is implementing voice or an HR practice equivalent to a technology adoption decision? First, individual workplaces are not born with a voice regime or HCHRM system in place, meaning that there is an explicit adoption decision to consider. The timing of adoption is governed by the profitability and the arbitrage conditions. ${ }^{2}$ Adoption also resembles "switching"

\footnotetext{
${ }^{1}$ Hannan et al. (2004) study organizational inertia using a simulation model. While inertia in their study can be interpreted in many ways, the notion that firms are exposed to risks when undergoing an organizational transformation resonates with our intuition of workplaces implementing differences HRM practices. Uncertainty being the cause of adoption delays is one of the lines of reasoning we will test in this paper. ${ }^{2}$ The profitability condition states that adoption must be convey positive benefits at the time of adoption, and the arbitrage condition postulates that waiting (arbitrage over time) is not profitable (Stoneman, 2002).
} 
- e.g. from a no-voice default to some form of voice - which calls for an assessment of switching costs, sunk costs and replacement effects.

For any technology or process innovation, there may also exist significant set-up costs even in the absence of purchasing costs. In our case these could include hiring HR expertise with specific knowledge of industry and firm characteristics. These costs may differ across workplaces and decrease over time, as the supply of this HR expertise increases.

Thus, it seems straightforward to view high-commitment HRM practices and voice as technologies, save for the absence of a "seller" and a "buyer" of voice or HRM technology. After all, firms do not "purchase" HRM practices or voice regimes necessarily, they merely choose to adopt them. Taking this argument further, however, would suggest that in the absence of this cost and the existence of positive benefits, all firms should have adopted voice and high-commitment HR practices by now. As this is clearly not the case, our analogy holds as there still seem to be significant non-pecuniary cost (e.g. learning cost) that deter firms from adopting voice or progressive HR practices ubiquitously. What is important for the voice and HCHRM as technology approach is that (1) net benefits differ across establishments for a host of reasons, (2) that they vary over time, and (3) that they may be negative for some firms at some points in time. This framework works well where establishments have discretion in whether to adopt voice and HR practices or not. Indeed, one can think of situations where because of federal statue or EU law, the workplace is obligated to provide a formal voice regime to its employees. In such cases, the state has effectively "set a technology standard" for all workplaces, perhaps cognizant of the uneven diffusion patterns that are present in the absence of outside policy intervention. ${ }^{3}$

The intuition above sets up our use of more formal models that can generate technological diffusion, i.e., the uneven and staggered adoption of an otherwise profitable

\footnotetext{
${ }^{3}$ Cabral and Kretschmer (forthcoming) propose a formal model of a standard-setting policymaker which takes the costs of non-standardization into account and derives policy implications as a function of the relative importance of these costs. Koski and Kretschmer (2004) give an overview over recent empirical work in standardization.
} 
technology. Nelson et al. (2004) classify different diffusion processes according to the degree of dynamic increasing returns (e.g. through network effects, competitive advantage or economies of learning and scale) and the ability to gather "sharp", i.e. objectively verifiable information on the technology (e.g. through information transmission and learning). Along similar lines, Geroski (2000) distinguishes between several effects that could generate technology diffusion. In particular, he identifies (1) the epidemic, (2) heterogeneity, (3) population ecology and (4) network effect approaches as possible generators of a staggered diffusion curve. We present each of these models below and extend the logic to cover questions of uneven HRM and voice adoption.

\subsection{The Epidemic Approach to Voice and HRM Adoption}

The epidemic approach (or variants of it) states that the net benefit of a technology is not known ex ante and that adopters learn over time. In the basic model, they learn about the technology's existence, while in information-cascade-type models, knowledge (or signals) of the technology's quality are revealed by the adoption decisions of other users (Bikhchandani et al. ,1989). In both cases, knowledge can emerge exogenously (independent of adoption decisions) or endogenously (adoption-dependent). In the context of HRM and voice adoption, one could imagine that the age of the establishment, having access to information through employer affiliations or being part of a larger multi-unit firm network, would all be factors conducive to the increased (faster) adoption of HRM and voice-type offerings at the workplace level. Although relying on a different modelling approach, these latter two possibilities have already have been found to increase the likelihood of adoption of HRM intensive practices in the U.S. (Eriksson and Jacoby, 2003).

\subsection{The Heterogeneity Approach to Voice and HRM Adoption}

The heterogeneity approach ranks firms by their propensity to adopt a new technology and postulates that firms deriving higher utility from adopting the technology will do so first (i.e., rank effect). The preference ranking can originate from a whole host of factors, including benefits 
(real or perceived) or costs (pecuniary and non-pecuniary) of adoption arising from absorptive capacity, switching cost, and usage of other complementary or substitute technologies. Under certain distributional assumptions, ${ }^{4}$ this approach will also generate an s-shaped diffusion pattern.

In our case it seems intuitive that the benefits of high-commitment HRM and voice would be greater the larger the establishment. Establishment size increases employee alienation and supervisory costs. Workplaces faced with these problems are more likely to offer a grievance procedure and some form of self-monitoring, both of which can be engendered by voice and progressive HR practices. Conversely, the benefits of remaining voice free and still gaining valuable information from employees are greater the smaller the establishment.

In terms of perceived benefits, the heterogeneity approach leads us to another set of predictions regarding risk and variables such as size and ownership. Agent decision making often displays puzzling departures from standard expected utility theory. In particular, it has been observed that agents become more risk taking as the potential prospects (returns) they face get larger (Astebro, 2004 and Starmer, 2000). In the context of HR and voice adoption, a firm would always be better off if it could appropriate all the benefits of voice without having to adopt a regime in the first place. This, however, is a risky decision and the tendency for that risky decision to occur, should increase as the prospects (returns) get better. In small owner-operated workplaces or in private (as opposed to public) sector workplaces, the potential returns of adopting voice for on owner-manager as the residual claimant are clearly greater than if a firm is run by management or is under state ownership (Astebro, 2004). One would expect that workplaces with less to gain (or more to lose) from non-adoption will be more likely to adopt voice or intense HRM, while owner-operated establishments with more to gain are more likely to remain HRM and voice-free.

\footnotetext{
${ }^{4}$ Effectively, any distribution with a single peak in between the extreme values (e.g. a normal distribution) is sufficient.
} 
The heterogeneity approach also notes the important role played by the costs of adoption. Adoption costs are especially relevant to small firms, as employing a sophisticated voice regime is not "cheap". To the extent that some scale economies may be at work, this would work in favour of size being positively related to voice and HRM adoption. Costs may also arise after adoption, in the form of switching costs. Technologies often create lock-in affects (i.e., the more accustomed a workplace becomes to a certain way of doing things, the more costly it becomes to switch-out). Switching costs may be larger for certain voice regimes and HCHRM practices, which could explain the slower diffusion profiles for these technologies, as the existence of lockin induces delay on the part of potential adopters.

In the case of HRM and voice, switching costs are have been affected by legal shifts and policy changes, since the early 1980s made union-free voice a more viable option for new establishments. Furthermore, because union voice necessarily involves a third party, it entails larger switching costs and hence one would expect that the incidence of union voice to be linked to set-up date - as establishments set up following these policy changes would face higher cost of switching out of union voice

Finally, the heterogeneity approach recognizes that the presence of substitute or complementary technologies could affect the adoption decision. In this case, since there are two technologies (HCHRM and voice) one can assess the well known contention (mostly found in the American literature) that a number of progressive HRM practices are substitutes for union voice, or equally, that union voice prevents firms from adopting the full panoply of progressive HRM policies.

\subsection{The Population Ecology Approach to Voice and HRM Adoption}

The population ecology approach relies on two factors to explain the gradual diffusion of technologies: a new technology of uncertain benefit may confer a competitive advantage to adopters. Early adopters will test the waters and if they are observed to improve their performance, will be imitated by later adopters. This imitation behaviour is termed the 
legitimisation effect - whatever is used by others is likely to be profitable. On the other hand, the advantage that the new technology confers will decrease as the number of adopters increases- a technology used by everybody cannot be a source of competitive advantage. This will slow down adoption by non-adopters - this is called the competition effect. These two counteracting forces may be reflected in several variables in our dataset, such as the extent of industry-wide adoption, set-up date and age of establishment. Because the legitimisation and competition effects work in opposite directions, these variables may well display effects that are non-linear.

\subsection{The Network-Effect Approach to Voice and HRM Adoption}

Finally, network effects may contribute to the uneven diffusion of a technology. Early adopters (which may have a higher propensity to adopt) will not benefit much from other adopters, while for later adopters network benefits are more important. The inclusion of lagged industry adoption levels of voice (the only variable for which we have longitudinal data) if positive, would suggest that voice is a network good. The actual mechanism could be as follows: to the extent that a voice regime shared by up-stream and down-stream establishments within an industry makes employee hiring and training easier and less costly, it makes sense that there could be spillovers by industry (e.g. through staff fluctuation) or through the dispersion of economy-wide information (e.g. through the training of HR consultants who then work in several different jobs within an industry).

\subsection{Hypotheses}

The hypotheses on the adoption probabilities (and speed) of voice and HCHRM adoption that we can derive from the various diffusion models above can be summarized as follows:

1. The size of inter- and intra-establishment networks positively affects the probability of voice and HCHRM adoption (epidemic model - learning and information spreading).

2. Establishment size positively affects the probability of voice and HCHRM adoption (heterogeneity model - benefits). 
3. Workplaces set up post 1980 will have a lower probability of voice and HCHRM adoption than older firms (heterogeneity model - switching cost).

4. Public ownership (vs. family ownership) and for-profit orientation (vs. governmentsector) positively affect the probability of adoption of voice and HCHRM (heterogeneity model - expected utility and residual claimancy).

5. Aggregate industry adoption positively affects voice and HCHRM probabilities (network effects).

6. Voice and HCHRM adoption are positively correlated (supermodularity).

In the following section, we specify several tests of the explanations above for the staggered diffusion of voice and HCHRM technology.

\section{The Data}

We use the British Workplace Industrial Relations Surveys (WIRS), which consist of large scale repeated surveys of industrial relations in British establishments in the public and private sectors that have been conducted on four occasions - 1980, 1984, 1990 and 1998. The key features of this data set are described elsewhere (Millward et al., 2000, 3-10; 248-55, Michie and Sheehan, 1999). Our analysis is based on data collected from Human Resource managers responsible for the workplace industrial relations in the 1984, 1990 and 1998 surveys, which contain the voicerelated variables needed for our analysis. All analyses are weighted by the inverse of the workplace's probability of selection for the survey. With these weights, our analyses provide a representative portrait of workplaces in Britain with $25+$ employees at the time of the surveys. The size threshold for inclusion in WIRS was dropped to 10 employees in 1998 . When analyses are confined to this 1998 survey, we include all workplaces with 10 or more employees. 
No-voice workplaces are defined by the absence of two-way forms of (representative or direct) communication between workers and management. Specifically, in our data, to be considered a no-voice establishment a workplace must lack the following:

- union recognition

- union representatives on or off site

- a joint consultative committee meeting at least once a month

- non-union representatives on site*

- problem solving groups*

- regular meetings between management and employees which allow for two-way communication

- team briefings that occur at least once a month and devote time to employees' questions/views.

The starred items indicate measures available in the 1998 survey only. In the time-series analysis that follows we employ a narrow no-voice definition (lacking the additional 1998 measures) to make 1984-1998 comparisons. When analyses are confined to 1998, we consider the sensitivity of our results to the use of the broad definition which includes them.

For our measure of high-commitment human resource management practices, ${ }^{5}$ we base our HRM intensity variable on managerial concepts outlined by Pfeffer (1995), in which he explains how to produce a sustainable competitive advantage through the effective management of people. The dimensions captured are:

(1) selectivity in recruiting,

(2) employment security,

(3) incentive pay,

(4) employee ownership,

\footnotetext{
${ }^{5}$ For a detailed explanation of the survey and construction of our HRM intensity measure, see Bryson (2001).
} 
(5) information sharing,

(6) participation and empowerment,

(7) self-managed teams,

(8) training and skill development,

(9) cross-utilisation and cross-training,

(10) symbolic egalitarianism,

(11) promotion from within.

In addition, the score includes an indicator that the workplace has a (12) formal strategic plan, strategic planning being a key component on HRM according to some commentators (Storey, 1992) and (13) widespread appraisal systems. A score of 13 would denote affirmative answers to each of these questions. Lacking any one of these HRM variables would give an establishment a score of 12 and so on. ${ }^{6}$

\section{The Empirical Approach}

Most studies of technology diffusion look at diffusion within a population, i.e. at aggregate figures (e.g. Koski and Kretschmer, forthcoming). With the availability of more detailed data, however, individual switching decisions can be analyzed (Astebro, 2004). Using workplace-level data, we pursue the second approach to explain the aggregate diffusion in the economy.

We assume that every workplace weighs current benefits and costs and make the decision to adopt or delay adoption depending on the net benefit's sign. We also include aggregate figures in the industry and economy to capture information and network effects. As we are analysing two "technologies" simultaneously (voice and HCHRM), we also test for the cross-effect between the

\footnotetext{
${ }^{6}$ Clearly, this is the simplest way of defining HRM intensity. Assigning different weights to each of these elements or using clusters of HRM practices does not fundamentally alter our conclusions (results available upon request).
} 
two to determine whether the technologies are supermodular (Milgrom and Roberts, 1995), i.e. if usage of one will affect the likelihood of adoption of the other technology.

Hypotheses 1 through 6 posited a positive relationship between voice and establishment characteristics such as public sector, workplace size, being part of a multi-establishment network, member of an employer association, and the extent of voice in an industry, controlling for other establishment-level variables such as industry (denoted $Z$ ). A negative effect was hypothesised between voice and family ownership. More nuanced outcomes were hypothesised for the determinants of voice-type; establishments with recent set up dates would be positively associated with non-union forms of voice and negatively with union-only voice. We use the following estimation model to test our hypotheses.

$$
\begin{aligned}
& \text { Prob }(\text { Voice }=1)_{i t}=\alpha_{1}+\delta_{1} \cdot \text { Public }_{i t}+\delta_{2} \text { Size }_{i t}+\delta_{3} \text { Network }_{i t}+\delta_{4} \text { Association }_{i t}
\end{aligned}
$$

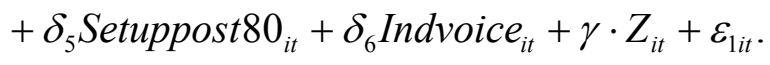

When we estimate this equation for voice and voice types (where 0 is no-voice in all cases), because we have three WERS data sets over three periods, we use a pooled times series estimate for [1]. This can account for cohort effects separately from pure age of establishment effects. However, the 1998 WERS contains a richer dataset which allows us to add variables such as age of establishment, family ownership vs. publicly owned (stock), size of the establishment network, and number of organisational affiliations (as well as type). We drop the time subscript $t$ when we focus on the 1998 WERS only. In all cases our estimates are presented in the easier to interpret linear probability estimate form. As these estimates are not qualitatively different from our logit estimates, we provide those upon request.

With respect to HCHRM intensity we estimate a similar model to [1], but since the HRM questions were only asked in the 1998 WERS survey, we are confined to that survey year only. We do, however, augment the model with the richer variable list available in the 1998 WERS, which among other things allows us to estimate the "cross-effect" between the two technologies, 
i.e., the association between voice and HCHRM intensity, as well as the potential substitutability of union voice and HCHRM.

$$
\begin{aligned}
& \text { [2] } \text { HRMscore }_{i}=\alpha_{1}+\delta_{1} \cdot \text { Public }_{i}+\delta_{2} \cdot \text { Familyowned }_{i}+ \\
& \delta_{2} \text { Size }_{i}+\delta_{3} \text { Networksize }_{i}+\delta_{4} \text { No.Associations }_{i}+\delta_{5} \text { Age }_{i}+\delta_{6} \text { Voice }_{i t}+\gamma \cdot Z_{i t}+\varepsilon_{1 i t} \text {. }
\end{aligned}
$$

When we estimate these equations for HRM intensity we also add a variant which codes a cut off of our score in order to designate "high" HRM intensity and the probability of an establishment falling above such a cut-off based on the variables highlighted above.

\section{$\underline{\text { 5. Results }}$}

We first present some basic descriptive data on voice, HRM intensity and the association between the two. As this is the only source of representative data for Britain on these variables, the descriptive results are interesting in their own right. Table 1 reports the incidence of voice for the pooled dataset and for the first (1984) and last (1998) wave of the WERS surveys. The overall rates are presented and also broken down by right-hand side variables. The percentage of establishments with some form of voice ranges for lows of 64.1 and 66.5 percent in singleestablishments and family owned operations respectively to a high of 98 percent in establishments with more than 1000 employees. The overall sample average for all establishments is 82.6 percent. Looking across row 1, there is no evidence of a change in the incidence of voice across the entire economy. However, these figures conceal considerable variations in voice type over time and across key variables such as set-up date, sector and industry.

In figures 3 and 4 we show adoption of voice in Britain by set-up date in the manufacturing and service industries. We see that manufacturing establishments have witnessed a fall in the incidence of voice, especially for those set up after 1980 (i.e., after post-Thatcher labor market reforms). Service sector establishments did not seem to differ by set-up date although there was an increase of 10 percentage points in voice adoption from 1984 to 1998. 
In terms of voice regime, the changes have been more dramatic over time within the voice sector. In figure 4 we see that non-union only forms of voice have witnessed a remarkable increase since 1984 (increasing from 15 percent of all workplaces in 1984 to nearly 45 percent by 1998), and this has occurred almost exclusively at the expense of union-only forms of voice. In fact, a decline is also apparent in dual forms of voice (union and non-union forms sitting side-byside).

Table 2 reports descriptive statistics (1998 only) on the use of high-commitment HRM practices, overall and disaggregated by key right-hand side variables. On average across establishments, 6.9 practices out of 13 are used, although this figure differs considerably across the variables highlighted in our six hypotheses. In particular small, single-establishment, family owned, private sector and middle-aged establishments use fewer HCHRM practices than larger, non-family owned, public sector, and younger or older establishments.

Table 2 also reports statistics for the "cross-effect" or the relation between voice (and voice type) and HRM intensity. It confirms that establishments with voice use more HCHRM practices. This is true across all forms of voice. However, within voice types, HCHRM intensity varies significantly. Union only voice clearly has the lowest HRM score amongst voice types, yet this should not be construed as evidence that union presence inside an establishment is necessarily detrimental to the adoption of HCHRM, as dual-forms of voice have a greater HRM score than non-union only. Another way into this question is to ask which HRM practices are more or less associated with certain voice types.

Tables 3 and 4 address that question. In Table 3 we list all 13 HRM practices and split the percentage breakdowns by whether a workplace has voice or not. We see that most practices are more likely to be found in a workplace that also has formal voice. In Table 4 we present the same set of 13 practices, but looking at patterns within the voice-using sector. We see that 
establishments with dual voice have a greater likelihood of adopting almost all HRM practices, except for the compensation related (extrinsic) components such as incentive pay and employee ownership schemes, where establishments with non-union only voice are more likely to use these two practices.

The empirical distribution of HRM practices by voice and voice type are graphically depicted in figures 5 and 6 . In figure 5 we see the rightward shift in HRM intensity that occurs for workplaces with voice as compared to those without. In figure 6 , across panels $\mathrm{A}$ through $\mathrm{C}$ we see the effect of voice-type on the empirical frequency of HRM practices. The panels are ranked in terms of overall mean in the HRM score, and we see how union-only voice with the lowest score also displays what unions seem to do everywhere, i.e., they compress the distribution of HRM scores. There are fewer outliers within the union voice type, with most firms located between 5 and 8 practices. In each panel the dotted line represents the overall frequency of scores.

Below we test if these relationships, which appear to confirm many of the conjectures in section 2, remain significant in our regression analysis.

\subsection{The Determinants of Voice Adoption}

We begin our analysis with a look at Table 5a. In this table we model the determinants of voice at the workplace using a linear probability model (logit estimates are similar and are available upon request). The coefficients can be interpreted as the percentage point change in voice adoption based on falling into one of our dependent categorical variable classifications. This table is limited in the number of RHS variables it can use since it pools all the data from 1984 to 1998 into one regression. The earlier survey waves included fewer questions and hence covariates. That being said, our results appear consistent with several of our hypotheses. In particular we find that: 
- Public (government) sector establishments are significantly more likely to adopt voice than private sector establishments (all things equal), consistent with the effect of ownership type on risk taking behavior,

- Establishment size, as measured by number of employees, is positively related to voice adoption, consistent with the heterogeneity approach and benefits of voice rising with establishment size, and

- Being part of a multi-establishment firm network or an employer association, as opposed to being a single-establishment non-member, increases the likelihood of adopting voice by 16 and 9 percentage points respectively, a confirmation of our epidemic/cascade model predictions.

Many of these findings are replicated across union and dual voice types, but workplaces with non-union only voice seem to differ from some of these generalizations:

- Non-union voice only workplaces are on average smaller and less likely to be publicsector workplaces.

- Whereas for all forms of voice set-up date proves insignificant, it does so because there are offsetting effects between union/dual voice and non-union only forms. An establishment set up after 1980 is 10 percentage points more likely to adopt non-union voice, whereas an otherwise similar workplace is 9 and 3 percentage points less likely to have dual or union only form of voice respectively. This confirms our switching cost prediction; i.e., union voice has greatest potential lock-in, newly established workplaces would be expected to avoid adopting it once regulatory constraints (the end of the closed shop) are lifted.

As a test of network effects, we ran the same model as above, replacing individual industry dummies with a measure of voice incidence in the industry that the workplace was part of in the previous period. For example, we ran the same model as in Table 5a using 1998 data only, but entering the 1990 incidence of industry voice for each establishment. The results in Table 5b are 
insignificant for voice overall, but strong network effects were found in the case of dual voice. That is, the greater the spread of dual voice in an industry in 1990, the greater the likelihood of a workplace in that industry adopting it in 1998. Insignificant negative effects were found for union-only and non-union only voice.

Table 5c reports estimates of [1] with 1998 data only. In the first column we use overall voice as our dependent variable and find that as anticipated, even after controlling for size of establishment and a host of other controls, family ownership exerts a strong negative effect on voice as compared to all other forms of ownership. This is consistent with the heterogeneity approach to diffusion and the potentially larger returns from not investing in voice that accrue to a single owner, inducing less adoption. All other variables carry the expected sign, including the indeterminate effects that come from workplace age, as the legitimization and competition effects appear to counteract each other and lead to insignificant age-related effects for voice adoption.

\subsection{The Determinants of HRM Intensity}

Table 6 reports estimates of models for HCHRM adoption and intensity. In the first column are the results of a dummy variable, which uses a cut-off of 9 HRM practices to denote a high HCHRM score (other cut-offs were tried and results were not significant different; results available upon request). We then explore the robustness of these results to a change in dependent variable, where the HRM intensity score is used. This score takes on a maximum value of 13 and a minimum of 0 . In column (2) the mean score was 6.89 and as our results are qualitatively the same in both columns, we will confine our interpretation of results to the more intuitive HRM score results. When we look at our variables of interest we find that:

- Workplace size once again has a positive and significant effect on the number of HRM practices adopted. 
- Workplaces that are part of some multi-establishment network also adopt more HCHRM practices, with the number of those practices increasing with network size;

- Age of establishment displays the inverted-U shape hypothesized as a result of the offsetting effects of the legitimization and competition effects. Workplaces aged 3 to 4 years are the most intensive users of HCHRM, while those aged under 3 and more than 21 years have lower scores;

- Organizational affiliations generally increase the use HCHRM up to a point, as the highest category (4 affiliations) seems to make little difference. Workplaces with three organizational affiliations have the highest use of HCHRM, consistent with our epidemic learning models;

- Finally, in terms of the hypothesized cross-effect between voice and HCHRM technologies, we find a more differentiated picture than previously explored. Consistent with much of literature, union only voice and HCHRM appear as substitutes, although the effect is small in magnitude. However, compared to workplaces with no voice, those with dual voice actually display the most intensive use of HCHRM, followed by non-union only.

\section{$\underline{5.3 \text { Implications }}$}

So what do these results tell us about the uneven adoption of voice and HCHRM across workplaces? Firstly, our results suggest that voice and HCHRM are supermodular, at least in the sense that the two most common forms of voice, dual and non-union only, are linked positively with HCHRM practices. Union-only voice appears to be negatively related to HCHRM practices. This is an important finding as it suggests that union presence per se does not diminish HCHRM adoption, as dual channel voice (where both management and union forms of collective representation) was linked with the largest incidence of HCHRM adoption. We also find that scale and epidemic effects, reflected in variables capturing workplace size and size of multi- 
establishment network, explain a large part of the differences in adoption of voice and HCHRM across workplaces. This seems to confirm the idea that substantial non-pecuniary (learning effects) and non-obligatory costs (i.e., the hiring of HRM specialists) play a substantial role in preventing ubiquitous adoption.

Adoption costs, especially switching costs, seem to play a role in that the likelihood of union-only voice is strongly linked to set-up date. Workplaces set up after 1980 were significantly less likely to adopt any form of union voice (union only or dual). Because it is harder to abandon union voice -- as it involves getting rid of a third party i.e., the union -- than it is to abandon a management-led form of voice, this induces delay and encourages the adoption of easier-toabandon technologies.

Information about HCHRM and voice, as well as the diffusion of best practices, also seem to play a role in adoption, as reflected in our age and organizational affiliation variables. We should note, however, that for both voice and HCHRM, the age of establishment variable exhibited the counteracting effects of the population ecology's legitimization and competition effects. The newer the HCHRM practice, the more workplaces that are initially needed to adopt in order to induce latecomers to also adopt. However, once many adopt, the advantage is lost and fewer firms then join in the wave, creating an optimal age at which adoption is most likely to occur (i.e., in our case 3 to 4 years of age).

We found strong evidence that family owned firms have a different perceived benefit function than non-family owned firms. Family owned firms, even after controlling for size, multiestablishment, and industry were significantly less likely to adopt voice and use HCHRM practices. This result is consistent with the idea that every organization would in theory be better off not investing in voice and HCHRM, if it thought it could nevertheless reap all the benefits of these technologies (i.e., better effort, greater motivation, lower turnover etc.) without formal 
adoption. This is a risky decision, however, and workplaces in the public sector or management run are less likely to make. ${ }^{7}$

\section{Conclusion.}

In this paper we treated voice and HCHRM as technological innovations and explained why this approach could help account for the uneven adoption patterns observed across British establishments. Specifically, we used Workplace Employment Relations Survey (WERS) data from 1984 to 1998 to answer a series of longstanding questions. We asked whether the presence of voice was a significant predictor of HCHRM intensity. The positive effect we found suggests that the two technologies are "supermodular" (Milgrom and Roberts, 1995). As a corollary we also wanted to know which voice-type (i.e., union, dual or non-union) was most strongly linked to HCHRM intensity. These were important questions as it is often argued that HCHRM and union voice appear to be substitutes at the workplace. We found that the answer to this question is more nuanced than previously thought. While union-only voice does seem to be negatively related to HCHRM intensity, the presence of a union does not necessarily diminish HCHRM adoption. In fact, we found that workplaces with dual forms of voice (union and non-union side-by-side) had the highest HCHRM scores.

We also asked which workplace characteristics were likely to increase the net benefit (and hence adoption) of voice and HCHRM. The variables were drawn from our appropriation of technology diffusion models to the question of voice and HCHRM adoption. We found significant effects for size of establishment, age, organisational affiliations, size of multiestablishment networks and some evidence of network effects for dual voice. Finally, we provided an explanation for why it is that sector (government versus private) and ownership

\footnotetext{
${ }^{7}$ These results may be explained by behavioral models which posit that when agents are faced with appropriating all the returns to some project, they gamble by not investing in voice or HCHRM. This latter result may also be a factor explaining the strong public sector effect present in our voice estimations.
} 
(family owned/operated versus management run) remain such significant predictors of voice and HCHRM adoption across workplaces, even after controlling for standard explanations such as workplace size and industry. The reason seems linked to a difference in perceived benefits, which can be explained by models of non-expected utility. 


\section{References}

Astebro, T. (2004). "The Return to Independent Invention: Evidence of Unrealistic Optimism, Risk Seeking or Skewness Loving?” The Economic Journal 113, pp. 226-239.

Baker, T. (1999). Doing Well by Doing Good: The Bottom Line on Workplace Practices. The Economic Policy Institute, Washington, D.C..

Bikhchandani, S., Hirshleifer, D. and Welch, I. (1992). "A Theory of Fads, Fashion, Custom, and Cultural Change as Informational Cascades." Journal of Political Economy 100, 992-1026.

Bryson, A. (2001): "Union Effects On Managerial and Employee Perceptions of Employee Relations in Britain.”, CEP Discussion Paper No. 494.

Cabral, L. and Kretschmer, T. (forthcoming): "Standards Battles and Public Policy." Forthcoming in S. Greenstein and V. Stango, Standards and Public Policy, Cambridge University Press, Cambridge.

Erikson, C. and Jacoby, S. (2003). "Management Matters: Employer Networks and Human Resource Innovations." Industrial and Labour Relations Review 56, no.2, 213-236.

Eriksson, T. (2002). "The Effects of New Work Practices. Evidence from Employer-Employee Data." Forthcoming in Advances in the Economic Analysis of Participatory and Labor-Managed Firms (eds. T. Kato and J. Pliskin), Vol. 7.

Geroski, P. (2000). “Models of Technology Diffusion”, Research Policy 29, 603-625.

Godard, J . (2004). "A Critical Assessment of the High-Performance Paradigm.” British Journal of Industrial Relations 42, pp. 349-378.

Hannan, M., Pólos, L. and Carroll, G. (2004). "The Evolution of Inertia." Industrial and Corporate Change 13, 213-242.

Ichniowski, C., Shaw, K. and Prennushi, G. (1997). "The Effects of Human

Resource Management on Productivity." American Economic Review 87, pp. 291-313.

Koski, H. and Kretschmer, T. (forthcoming). "Entry, Standards and Competition: Firm Strategies and the Diffusion of Mobile Telephony." Forthcoming in Review of Industrial Organization.

Koski, H. and Kretschmer, T. (2004). "Survey on Competing in Network Industries: Firm Strategies, Market Outcomes, and Policy Implications." Journal of Industry, Competition and Trade 4, 5-31.

Milgrom, P. and Roberts, J. (1995). "Complementarities and Fit: Structure and Organizational Change in Manufacturing." Journal of Accounting and Economics 19, pp. 179208.

Michie, J. and Sheehan, M. (1999). "HRM practices, R\&D expenditure and innovative investment: evidence from the UK's 1990 workplace industrial relations survey (WIRS)", Industrial and Corporate Change, 8, 211-234. 
Millward, N., Bryson, A. and Forth, J. (2000). “All Change at Work?” British Employment Relations 1980-1998, as Portrayed by the Workplace Industrial Relations Survey Series. Routledge, London.

Nelson, R., Peterhansl, A. and Sampat, B. (2004). "Why and How Innovations Get Adopted: a tale of four models." Industrial and Corporate Change 13, 679-699.

Pfeffer, J. (1995). "Producing sustainable competitive advantage through the effective management of people," Academy of Management Executive 9, pp. 55-72

Starmer, C. (2000). "Developments in Non-expected Utility Theory: The Hunt for a Descriptive Theory of Choice under Risk," Journal of Economic Literature 38, pp. 332-382.

Stoneman, P. (2002). The Economics of Technological Diffusion. Blackwell, Oxford.

Storey, J. (1992). Developments in the Management of Human Resources. Blackwell, Oxford.

Willman, P., Bryson, A., and Gomez, R. (2004). "The End of the Affair? The Decline in Employers' Propensity to Unionize", Chapter 8 in J. Kelly and P. Willman (eds.), Union Organization and Activity, Routledge, London, pp.129-149. 
Table 1: Incidence of Voice by Selected Workplace Characteristics, 1984-1998

\begin{tabular}{|c|c|c|c|}
\hline & \multicolumn{3}{|c|}{ Percentages } \\
\hline & $\begin{array}{c}\text { Pooled data } \\
(1984,1990 \\
\text { and 1998) }\end{array}$ & 1984 & 1998 \\
\hline 1. All Workplaces & 82.6 & 83.6 & 83.1 \\
\hline 2. By Sector & & & \\
\hline Public & 98.2 & 99.7 & 98.9 \\
\hline Private services & 76.5 & 72.3 & 80.8 \\
\hline Private manufacturing & 72.8 & 78.2 & 65.2 \\
\hline 3. By Establishment size (employees) & & & \\
\hline $25-49$ & 77.8 & 78.4 & 79.5 \\
\hline $50-99$ & 80.4 & 86.1 & 82.7 \\
\hline 100-199 & 90.4 & 91.2 & 89.9 \\
\hline $200-499$ & 94.5 & 94.1 & 93.5 \\
\hline $500-999$ & 96.2 & 97.3 & 95.1 \\
\hline 1000 plus & 98.2 & 99.9 & 96.5 \\
\hline 4. By Ownership & & & \\
\hline Foreign & 74.6 & 79.8 & 72.5 \\
\hline Domestic & 83.1 & 83.8 & 84.2 \\
\hline 5. By Establishment & & & \\
\hline Single & 64.1 & 59.5 & 70.7 \\
\hline Multi-establishment & 88.0 & 89.0 & 87.7 \\
\hline 6. By Size of Multi-Establishment Network* & & & \\
\hline Single & 71.8 & -- & 71.8 \\
\hline $2-10$ & 83.9 & -- & 83.9 \\
\hline $11-50$ & 83.3 & -- & 83.3 \\
\hline $50+$ & 92.5 & -- & 92.5 \\
\hline 7. By Set-up date & & & \\
\hline Pre 1980 & 84.5 & 83.7 & 88.5 \\
\hline Post 1980 & 78.6 & 82.8 & 78.5 \\
\hline 8. By Decade of Set-up date & & & \\
\hline Pre 1980 & 84.5 & -- & -- \\
\hline $1980 \mathrm{~s}$ & 77.7 & -- & -- \\
\hline $1990 \mathrm{~s}$ & 78.7 & -- & -- \\
\hline 9. By Establishment Age* & & & \\
\hline$<3$ years & 80.0 & -- & 80.0 \\
\hline $3-19$ years & 82.1 & -- & 82.1 \\
\hline $20+$ years & 86.1 & -- & 86.1 \\
\hline 10. By Industry & & & \\
\hline Manufacturing & 75.2 & 80.8 & 68.5 \\
\hline Electricity, gas and water & 99.4 & 99.0 & 99.9 \\
\hline Construction & 64.5 & 66.4 & 70.5 \\
\hline Wholesale and retail & 78.7 & 74.2 & 83.3 \\
\hline Transport + Communication & 86.9 & 93.8 & 86.0 \\
\hline Financial services & 75.8 & 71.4 & 76.8 \\
\hline Other business services & 93.3 & 94.9 & 93.6 \\
\hline Public administration & 98.4 & 94.9 & 99.9 \\
\hline Education & 96.7 & 98.7 & 98.7 \\
\hline Health & 99.2 & 99.9 & 99.9 \\
\hline Other community services & 99.3 & 99.9 & 98.1 \\
\hline 11. By HRM Score* & & & \\
\hline High [9-13] & 93.6 & -- & 93.6 \\
\hline Low $[0-8]$ & 80.0 & -- & 80.0 \\
\hline 12. By Ownership Structure* & & & \\
\hline Family owned/controlled & 66.5 & -- & 66.5 \\
\hline Other & 88.8 & -- & 88.8 \\
\hline 13. By Employer Association Status & & & \\
\hline Yes & 85.1 & 88.4 & 87.9 \\
\hline No & 80.1 & 82.5 & 82.9 \\
\hline
\end{tabular}




\begin{tabular}{|l|c|c|c|}
\hline 14. By Number of Organizational Affiliations* & & & \\
None & 82.9 & -- & 82.9 \\
One & 82.1 & -- & 82.1 \\
Two & 85.3 & -- & 85.3 \\
Three & 87.9 & -- & 87.9 \\
Four & 99.4 & -- & 99.4 \\
\hline 15. By Franchise Status* & 91.7 & - & \\
Franchisee & 83.1 & -- & 81.7 \\
Non-franchisee & 5742 & 1885 & 1954 \\
\hline
\end{tabular}

Source: Data are for Britain using WERS/WIRS data, 1984, 1990, 1998. *Available for WERS 1998 only. Workplaces with $25+$ employees 
Table 2: Average High Commitment HRM Score (score 1 to 13) actual and Z-scores by selected workplace characteristics, 1998.

\begin{tabular}{|c|c|c|}
\hline & $\begin{array}{c}\text { Average HRM } \\
\text { Score } \\
\end{array}$ & $\begin{array}{c}\text { Normalised } \\
\text { Z-Score }\end{array}$ \\
\hline 1. All Workplaces & 6.9 & $0.09^{*}$ \\
\hline 2. By Sector & & \\
\hline Public & 7.45 & 6.22 \\
\hline Private & 6.71 & -2.00 \\
\hline 3. By Establishment size (employees) & & \\
\hline $10-24$ & 6.6 & -3.22 \\
\hline $25-49$ & 6.94 & 0.56 \\
\hline $50-99$ & 7.19 & 3.33 \\
\hline 100-199 & 7.59 & 7.78 \\
\hline $200-499$ & 7.93 & 11.56 \\
\hline $500+$ & 8.05 & 12.89 \\
\hline 4. By Ownership & & \\
\hline Foreign & 7.15 & 2.89 \\
\hline Domestic & 6.89 & 0.00 \\
\hline Joint Venture & 5.81 & -12.00 \\
\hline 5. By Establishment & & \\
\hline Single & 5.81 & -12.00 \\
\hline Multi-establishment & 7.39 & 5.56 \\
\hline 6. By Size of Multi-Establishment Network & & \\
\hline Single & 5.83 & -11.78 \\
\hline $2-10$ & 7.03 & 1.56 \\
\hline $11-50$ & 6.87 & -0.22 \\
\hline $51+$ & 7.98 & 12.11 \\
\hline 7. By Organization Size & & \\
\hline Small $[<50]$ & 6.60 & -3.22 \\
\hline Large $[51+]$ & 7.92 & 11.44 \\
\hline 8. By Establishment Age & & \\
\hline$<3$ years & 6.44 & -5.00 \\
\hline $3-19$ years & 7.20 & 3.44 \\
\hline $20+$ years & 6.64 & -2.78 \\
\hline 9. By Industry & & \\
\hline Manufacturing & 6.01 & -9.78 \\
\hline Electricity, gas and water & 9.19 & 25.56 \\
\hline Construction & 5.11 & -19.78 \\
\hline Wholesale and retail & 7.31 & 4.67 \\
\hline Hotels and restaurants & 6.56 & -3.67 \\
\hline Transport + Communication & 7.10 & 2.33 \\
\hline Financial services & 8.65 & 19.56 \\
\hline Other business services & 7.14 & 2.78 \\
\hline Public administration & 7.17 & 3.11 \\
\hline Education & 7.42 & 5.89 \\
\hline Health & 7.15 & 2.89 \\
\hline Other community services & 5.56 & -14.78 \\
\hline 10. By Ownership & & \\
\hline Family owned/controlled & 5.93 & -10.67 \\
\hline Other & 7.22 & 3.67 \\
\hline 11. By Employer Association Status & & \\
\hline Yes & 6.80 & -1.00 \\
\hline No & 6.88 & -0.11 \\
\hline 12. By Number of Organisational Affiliations & & \\
\hline 0 & 6.88 & -0.11 \\
\hline 1 & 6.67 & -2.44 \\
\hline 2 & 6.96 & 0.78 \\
\hline 3 & 7.08 & 2.11 \\
\hline 4 & 7.87 & 10.89 \\
\hline
\end{tabular}




\begin{tabular}{|l|c|c|}
\hline 13. By Franchise Status & 6.77 & -1.33 \\
Franchise & 6.90 & 0.11 \\
Non-franchise & & \\
\hline 14. By Type of Voice I & 5.71 & -13.11 \\
No Voice & 6.41 & -5.33 \\
Union & 6.86 & -0.33 \\
Non-Union Only & 7.51 & 6.89 \\
Dual Channel & & \\
\hline 15. By Type of Voice II & 5.71 & -13.11 \\
No Voice & 6.28 & -6.78 \\
Representative Only & 7.63 & 8.22 \\
Representative and Direct & 6.75 & -1.56 \\
Direct Only & & \\
\hline & 1929 & \\
Number of Observations & & \\
\hline
\end{tabular}

Source: Data are for Britain using WERS data 1998. *The figure 0.09 is the standard deviation for the sample. 
Table 3: Incidence of High Commitment HRM practices by workplaces with and without formal voice* (\%), 1998.

\begin{tabular}{|l|c|c|c|}
\hline \multirow{2}{*}{ High Commitment HRM Practices } & \multicolumn{2}{|c|}{ By Presence of Voice at workplace } \\
\cline { 2 - 4 } & No & Yes & All Workplaces \\
\hline 1. Presence of Formal Strategic Plan & 47.1 & 78.9 & 73.7 \\
2. Guaranteed Job Security & 7.2 & 10.9 & 10.3 \\
3. Selective Recruitment & 46.4 & 54.8 & 53.4 \\
4. Employee Ownership Scheme & 11.2 & 15.4 & 14.7 \\
5. Presence of Incentive Pay & 53.3 & 52.7 & 52.8 \\
6. Ongoing Training & 57.5 & 73.2 & 70.6 \\
7. Internal "Symbolic" Equity & 20.0 & 46.6 & 42.2 \\
8. Internal Promotion & 24.2 & 25.8 & 25.6 \\
9. Formal Appraisal System & 37.4 & 56.7 & 53.5 \\
10. Information Sharing & 57.5 & 73.2 & 79.9 \\
11. Self-Managed Teams & 62.6 & 77.5 & 75.0 \\
12. Job Enrichment & 61.2 & 70.1 & 68.6 \\
13. Participation and Empowerment & 69.9 & 59.5 & 61.1 \\
\hline Number of Observations & 346 & 1742 & 2088 \\
\hline
\end{tabular}

Notes: Source: Data are for Britain using WERS data 1998. Numbers in parentheses refer to sample proportions. *Broad definition of "voice" is used. 
Table 4: Incidence of High Commitment HRM practices by type of workplace voice* (\%), 1998.

\begin{tabular}{|c|c|c|c|}
\hline \multirow[b]{2}{*}{ Communication Practice } & \multicolumn{3}{|c|}{ Type of Formal voice } \\
\hline & Non-Union Only & Dual Channel & $\begin{array}{c}\text { Union } \\
\text { Only }\end{array}$ \\
\hline 1. Presence of Formal Strategic Plan & 74.4 & 87.7 & 72.7 \\
\hline 2. Guaranteed Job Security & 6.9 & 18.4 & 4.0 \\
\hline 3. Selective Recruitment & 48.5 & 67.2 & 41.1 \\
\hline 4. Employee Ownership Scheme & 16.8 & 14.4 & 8.3 \\
\hline 5. Presence of Incentive Pay & 61.3 & 41.2 & 39.4 \\
\hline 6. Ongoing Training & 72.1 & 75.0 & 67.7 \\
\hline 7. Internal "Symbolic" Equity & 41.9 & 53.7 & 49.7 \\
\hline 8. Internal Promotion & 26.5 & 26.5 & 16.1 \\
\hline 9. Formal Appraisal System & 59.9 & 53.8 & 42.5 \\
\hline 10. Information Sharing & 79.9 & 88.0 & 88.9 \\
\hline 11. Self-Managed Teams & 71.8 & 85.6 & 82.1 \\
\hline 12. Job Enrichment & 66.2 & 76.4 & 68.9 \\
\hline 13. Participation and Empowerment & 59.3 & 59.8 & 60.2 \\
\hline Number of Observations & $\begin{array}{c}1005 \\
(0.58)\end{array}$ & $\begin{array}{c}634 \\
(0.37)\end{array}$ & $\begin{array}{c}103 \\
(0.06)\end{array}$ \\
\hline
\end{tabular}

Notes: Source: Data are for Britain using WERS data 1998. Numbers in parentheses refer to sample proportions *Broad definition of "voice" is used. 
Table 5a: The Determinants of Voice at the Workplace, Pooled 1984-1998.

\begin{tabular}{|c|c|c|c|c|}
\hline & & inear Prob & ity Estim & \\
\hline & (1) & (2) & (3) & (4) \\
\hline Omitted reference category [No Voice] & & Depenc & Variable & \\
\hline & Voice & $\begin{array}{l}\text { Non- } \\
\text { Union }\end{array}$ & $\begin{array}{c}\text { Dual } \\
\text { Channel }\end{array}$ & $\begin{array}{l}\text { Union } \\
\text { Only }\end{array}$ \\
\hline Dependent Variable Mean & 0.82 & 0.29 & 0.37 & 0.15 \\
\hline 1. Public Sector [Private] & $\begin{array}{c}0.12 \\
(4.77)\end{array}$ & $\begin{array}{c}-0.32 \\
(-10.17)\end{array}$ & $\begin{array}{c}0.26 \\
(7.06)\end{array}$ & $\begin{array}{c}0.18 \\
(6.18)\end{array}$ \\
\hline 2. Foreign Owned [Domestic] & $\begin{array}{c}-0.07 \\
(-1.70) \\
\end{array}$ & $\begin{array}{c}0.02 \\
(0.46) \\
\end{array}$ & $\begin{array}{c}-0.06 \\
(-1.76) \\
\end{array}$ & $\begin{array}{c}-0.03 \\
(-1.52) \\
\end{array}$ \\
\hline 3. Workplace Size [25-49 employees] & & & & \\
\hline $50-99$ & $\begin{array}{c}0.07 \\
(3.19)\end{array}$ & $\begin{array}{c}0.03 \\
(1.35)\end{array}$ & $\begin{array}{c}0.02 \\
(0.77)\end{array}$ & $\begin{array}{c}0.02 \\
(1.30)\end{array}$ \\
\hline $100-199$ & $\begin{array}{c}0.11 \\
(5.79)\end{array}$ & $\begin{array}{l}-0.01 \\
(-0.55)\end{array}$ & $\begin{array}{c}0.08 \\
(3.53)\end{array}$ & $\begin{array}{c}0.05 \\
(2.43)\end{array}$ \\
\hline $200-499$ & $\begin{array}{c}0.15 \\
(7.36)\end{array}$ & $\begin{array}{c}-0.05 \\
(-2.05)\end{array}$ & $\begin{array}{c}0.14 \\
(5.88)\end{array}$ & $\begin{array}{c}0.05 \\
(2.19)\end{array}$ \\
\hline $500+$ & $\begin{array}{c}0.16 \\
(7.12) \\
\end{array}$ & $\begin{array}{c}-0.09 \\
(-4.10) \\
\end{array}$ & $\begin{array}{c}0.21 \\
(5.99) \\
\end{array}$ & $\begin{array}{c}0.04 \\
(1.20)\end{array}$ \\
\hline 4. Part of Establishment Network [Single] & $\begin{array}{c}0.16 \\
(5.37) \\
\end{array}$ & $\begin{array}{c}0.03 \\
(1.15) \\
\end{array}$ & $\begin{array}{c}0.18 \\
(8.90)\end{array}$ & $\begin{array}{c}0.01 \\
(0.47)\end{array}$ \\
\hline 5. Member of Employer Association [No] & $\begin{array}{c}0.09 \\
(3.24) \\
\end{array}$ & $\begin{array}{c}0.12 \\
(4.94) \\
\end{array}$ & $\begin{array}{c}0.12 \\
(4.27) \\
\end{array}$ & $\begin{array}{c}-0.09 \\
(-4.01) \\
\end{array}$ \\
\hline 6. By Set-up Date Post 1980 [Pre 1980] & $\begin{array}{c}-0.02 \\
(-0.72) \\
\end{array}$ & $\begin{array}{c}0.10 \\
(3.95) \\
\end{array}$ & $\begin{array}{c}-0.09 \\
(-3.94) \\
\end{array}$ & $\begin{array}{c}-0.03 \\
(-1.80) \\
\end{array}$ \\
\hline 7. Year Dummy [1998] & & & & \\
\hline 1984 & $\begin{array}{c}-0.03 \\
(-1.41)\end{array}$ & $\begin{array}{c}-0.14 \\
(-5.68)\end{array}$ & $\begin{array}{c}0.00 \\
(0.00)\end{array}$ & $\begin{array}{c}0.11 \\
(5.20)\end{array}$ \\
\hline 1990 & $\begin{array}{c}-0.02 \\
(-0.63) \\
\end{array}$ & $\begin{array}{c}-0.10 \\
(-3.39) \\
\end{array}$ & $\begin{array}{c}0.04 \\
(1.81) \\
\end{array}$ & $\begin{array}{c}0.04 \\
(2.32) \\
\end{array}$ \\
\hline 8. Industry SIC 1980 [Other services] & & & & \\
\hline Electricity, gas and water & $\begin{array}{c}0.04 \\
(1.62)\end{array}$ & $\begin{array}{c}-0.16 \\
(-4.02)\end{array}$ & $\begin{array}{c}0.05 \\
(0.53)\end{array}$ & $\begin{array}{c}0.16 \\
(1.89)\end{array}$ \\
\hline Mining, Fishing and Extraction & $\begin{array}{c}-0.10 \\
(-1.70)\end{array}$ & $\begin{array}{c}-0.16 \\
(-2.79)\end{array}$ & $\begin{array}{c}-0.09 \\
(-1.81)\end{array}$ & $\begin{array}{c}0.16 \\
(3.44)\end{array}$ \\
\hline Metal Industry Manufacturing & $\begin{array}{c}-0.15 \\
(-2.74)\end{array}$ & $\begin{array}{c}-0.12 \\
(-2.33)\end{array}$ & $\begin{array}{c}-0.12 \\
(-3.27)\end{array}$ & $\begin{array}{c}0.10 \\
(3.36)\end{array}$ \\
\hline Other Manufacturing & $\begin{array}{c}-0.09 \\
(-2.36)\end{array}$ & $\begin{array}{c}-0.14 \\
(-3.22)\end{array}$ & $\begin{array}{c}-0.09 \\
(-2.18)\end{array}$ & $\begin{array}{c}0.13 \\
(4.51)\end{array}$ \\
\hline Construction & $\begin{array}{l}-0.22 \\
(-4.07)\end{array}$ & $\begin{array}{c}-0.17 \\
(-3.43)\end{array}$ & $\begin{array}{c}-0.17 \\
(-3.88)\end{array}$ & $\begin{array}{c}0.12 \\
(2.66)\end{array}$ \\
\hline Hotels, Restaurants and Distribution & $\begin{array}{c}-0.06 \\
(-1.75)\end{array}$ & $\begin{array}{c}0.08 \\
(2.02)\end{array}$ & $\begin{array}{l}-0.17 \\
-4.79)\end{array}$ & $\begin{array}{c}0.03 \\
(1.34)\end{array}$ \\
\hline Transport and Communication & $\begin{array}{c}-0.03 \\
(-0.81)\end{array}$ & $\begin{array}{c}-0.16 \\
(-4.53)\end{array}$ & $\begin{array}{l}-0.00 \\
-0.22)\end{array}$ & $\begin{array}{c}0.15 \\
(4.11)\end{array}$ \\
\hline Financial Services & $\begin{array}{c}-0.08 \\
(-2.20) \\
\end{array}$ & $\begin{array}{c}-0.05 \\
(-1.28) \\
\end{array}$ & $\begin{array}{c}-0.07 \\
(-1.55) \\
\end{array}$ & $\begin{array}{c}0.04 \\
(1.18)\end{array}$ \\
\hline 9. Intercept & $\begin{array}{c}0.93 \\
(22.77) \\
\end{array}$ & $\begin{array}{c}0.36 \\
(7.94)\end{array}$ & $\begin{array}{c}0.49 \\
(11.21) \\
\end{array}$ & $\begin{array}{c}0.08 \\
(2.52) \\
\end{array}$ \\
\hline Observations & 4997 & 4997 & 4997 & 4997 \\
\hline R-squared & 0.21 & 0.20 & 0.22 & 0.22 \\
\hline
\end{tabular}

Notes: Linear probability estimates. Items in [ ] refer to omitted reference category. T-stats in parentheses. Workplaces include those $25+$ employees. *Narrow definition of voice employed. 
Table 5b: The effect of the extent of industry voice adoption in 1990 on individual workplace Voice* adoption in 1998.

\begin{tabular}{|l|c|c|}
\hline \multirow{2}{*}{ Forms of Voice } & \multicolumn{2}{|c|}{} \\
\cline { 2 - 3 } & Coefficient & t-value \\
\cline { 2 - 3 } & & \\
1. For All Voice & 0.175 & 0.52 \\
2. For Dual & 0.969 & 3.64 \\
3. For Non-Union only & -0.528 & -1.46 \\
4. For Union-Only & -0.175 & -0.52 \\
\hline
\end{tabular}

Note: Each row shows coefficients for the network effect variable, based on separate linear probability estimates with same controls as Table 5a except for industry dummies. Workplaces include those $25+$ employees. *Narrow definition of voice employed. 
Table 5c: The Determinants of Voice at the Workplace, 1998.

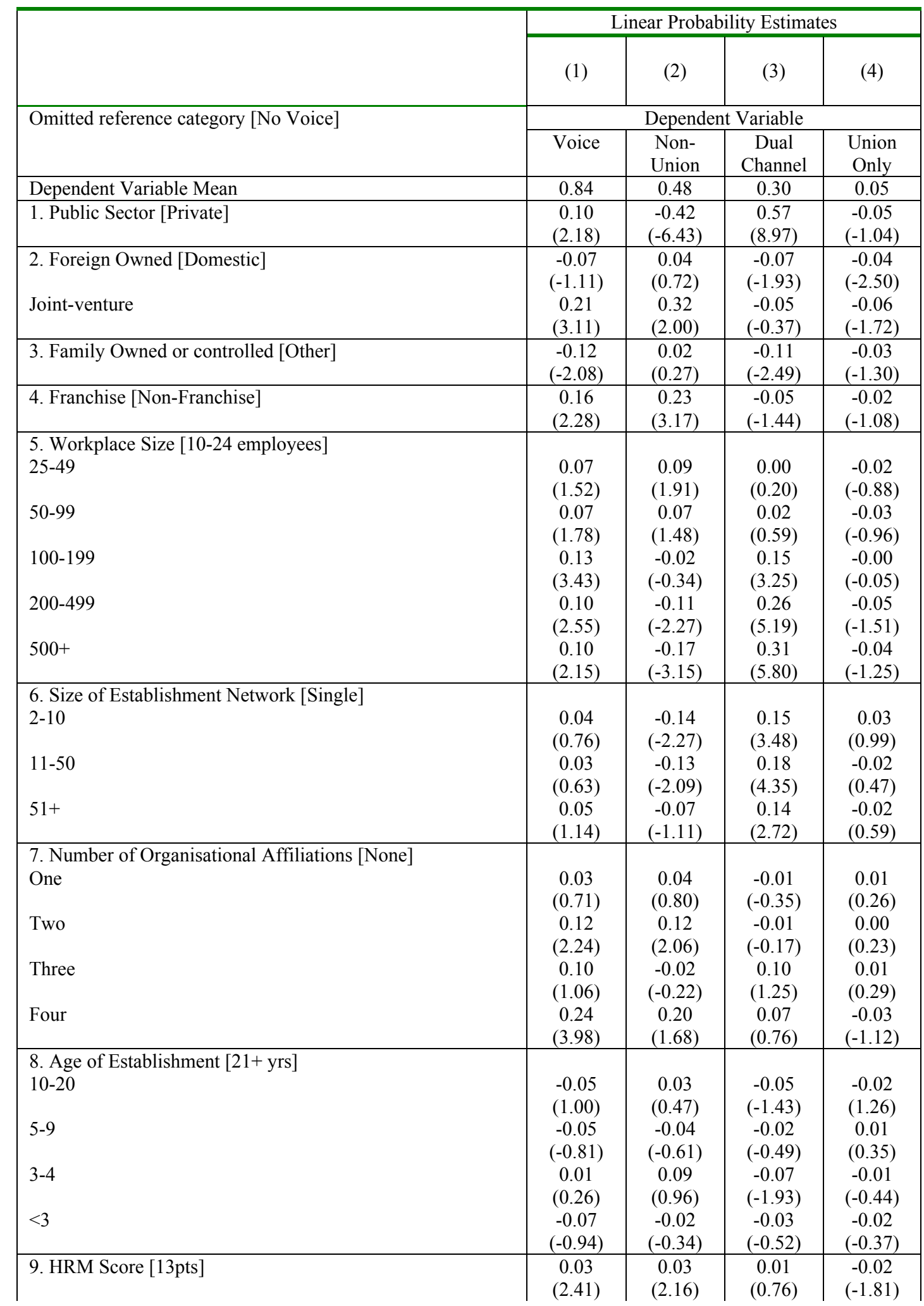




\begin{tabular}{|l|c|c|c|c|}
\hline 10. Industry [Wholesale and Retail] & & & & \\
Manufacturing & -0.07 & -0.29 & 0.16 & 0.07 \\
Electricity, gas and water & $(-0.81)$ & $(-3.52)$ & $(2.87)$ & $(1.58)$ \\
& 0.08 & -0.61 & 0.70 & -0.01 \\
Construction & $(1.44)$ & $(-8.89)$ & $(11.94)$ & $(-0.29)$ \\
& -0.12 & -0.25 & 0.05 & 0.08 \\
Hotels and restaurants & $(-1.11)$ & $(-2.13)$ & $(0.69)$ & $(1.24)$ \\
& -0.01 & 0.09 & -0.08 & -0.02 \\
Transport and communication & $(-0.12)$ & $(1.11)$ & $(-1.79)$ & $(-1.58)$ \\
& -0.07 & -0.24 & 0.12 & 0.05 \\
Financial services & $(-0.72)$ & $(-2.28)$ & $(1.59)$ & $(1.20)$ \\
& -0.06 & -0.34 & 0.38 & 0.02 \\
Other business services & $(1.08)$ & $(-3.16)$ & $(4.05)$ & $(0.82)$ \\
& 0.07 & 0.12 & -0.04 & -0.01 \\
Public administration & $(1.08)$ & $(1.57)$ & $(-0.90)$ & $(-0.65)$ \\
& 0.08 & -0.09 & 0.03 & 0.14 \\
Education & $(1.03)$ & $(-0.68)$ & $(0.19)$ & $(1.52)$ \\
Health & 0.03 & -0.03 & -0.05 & 0.11 \\
& $(0.40)$ & $(-0.28)$ & $(-0.75)$ & $(1.41)$ \\
Other community services & 0.02 & -0.12 & 0.11 & 0.04 \\
& $(0.29)$ & $(-1.37)$ & $(1.98)$ & $(1.32)$ \\
\hline 11. Intercept & 0.02 & 0.01 & 0.03 & -0.02 \\
& $(0.18)$ & $(0.10)$ & $(0.42)$ & $(-0.85)$ \\
\hline Observations & 0.66 & & 0.23 & 0.10 \\
\hline R-squared & $(6.13)$ & & $(2.89)$ & $(2.28)$ \\
\hline
\end{tabular}

Note: Items in [ ] refer to omitted reference category. 
Table 6: The Determinants of High Commitment HRM Intensity at the Workplace, 1998.

\begin{tabular}{|c|c|c|c|c|}
\hline \multirow{3}{*}{ Dep. Var. Mean } & \multicolumn{2}{|c|}{$\begin{array}{c}\text { Dependent variable: } \\
\text { High HRM Score Dummy } \\
\text { [Probit Estimates] }\end{array}$} & \multicolumn{2}{|c|}{$\begin{array}{c}\text { Dependent variable: } \\
\text { HRM Score } \\
{[\text { OLS }]} \\
\end{array}$} \\
\hline & & & & \\
\hline & Coefficient & t-stat & Coefficient & t-stat \\
\hline 1. Public Sector [Private] & -0.17 & -0.78 & -0.02 & -0.05 \\
\hline 2. Foreign Owned [Domestic] & 0.32 & 1.60 & 0.09 & 0.27 \\
\hline Joint-Venture & -0.36 & -3.45 & -1.91 & -3.48 \\
\hline 3. Family Owned or controlled [Other] & -0.60 & -3.22 & -0.56 & -2.34 \\
\hline 4. Franchise [Non-Franchise] & -0.04 & -0.12 & -0.21 & -0.43 \\
\hline $\begin{array}{l}\text { 5. Workplace Size [10-24 employees] } \\
25-49 \\
50-99 \\
100-199 \\
200-499 \\
500+ \\
\end{array}$ & $\begin{array}{l}0.06 \\
0.15 \\
0.42 \\
0.57 \\
0.60 \\
\end{array}$ & $\begin{array}{l}0.39 \\
1.00 \\
2.82 \\
3.70 \\
3.29 \\
\end{array}$ & $\begin{array}{l}0.08 \\
0.36 \\
0.81 \\
0.94 \\
1.13 \\
\end{array}$ & $\begin{array}{l}0.44 \\
1.76 \\
3.77 \\
4.17 \\
4.28 \\
\end{array}$ \\
\hline $\begin{array}{l}\text { 6. Size of Establishment Network [Single] } \\
2-10 \\
11-50 \\
51+\end{array}$ & $\begin{array}{r}0.46 \\
-0.03 \\
0.57 \\
\end{array}$ & $\begin{array}{r}2.50 \\
-0.98 \\
3.38 \\
\end{array}$ & $\begin{array}{l}1.46 \\
0.40 \\
0.88\end{array}$ & $\begin{array}{l}5.39 \\
1.47 \\
3.90\end{array}$ \\
\hline $\begin{array}{l}\text { 7. Age of Establishment }[21+\text { yrs }] \\
10-20 \\
5-9 \\
3-4 \\
<3\end{array}$ & $\begin{array}{l}0.24 \\
0.22 \\
0.51 \\
0.22\end{array}$ & $\begin{array}{l}1.49 \\
1.20 \\
2.13 \\
0.93\end{array}$ & $\begin{array}{l}0.51 \\
0.53 \\
0.94 \\
0.22\end{array}$ & $\begin{array}{l}2.31 \\
2.30 \\
2.96 \\
0.70\end{array}$ \\
\hline $\begin{array}{l}\text { 8. Number of Organizational Affiliations [None] } \\
\text { One } \\
\text { Two } \\
\text { Three } \\
\text { Four }\end{array}$ & $\begin{array}{r}0.02 \\
0.23 \\
0.52 \\
-0.15\end{array}$ & $\begin{array}{r}0.13 \\
1.29 \\
1.94 \\
-0.46\end{array}$ & $\begin{array}{l}0.03 \\
0.42 \\
0.75 \\
0.98\end{array}$ & $\begin{array}{l}0.21 \\
1.68 \\
1.88 \\
1.71\end{array}$ \\
\hline $\begin{array}{l}\text { 9. Type of Voice [No Voice] } \\
\text { Union only } \\
\text { Non-Union only } \\
\text { Dual Channel }\end{array}$ & $\begin{array}{r}-0.44 \\
0.52 \\
0.58 \\
\end{array}$ & $\begin{array}{r}-1.25 \\
1.97 \\
2.41 \\
\end{array}$ & $\begin{array}{c}-0.14 \\
0.59 \\
0.67 \\
\end{array}$ & $\begin{array}{r}-0.39 \\
1.93 \\
2.56 \\
\end{array}$ \\
\hline $\begin{array}{l}\text { 10.570. Industry [Wholesale and retail] } \\
\text { Manufacturing } \\
\text { Electricity, gas and water } \\
\text { Construction } \\
\text { Hotels and restaurants } \\
\text { Transport and communication } \\
\text { Financial services } \\
\text { Other business services } \\
\text { Public administration } \\
\text { Education } \\
\text { Health } \\
\text { Other community services }\end{array}$ & $\begin{array}{r}-0.65 \\
0.72 \\
-0.88 \\
-0.36 \\
-0.11 \\
-0.05 \\
-0.01 \\
-0.01 \\
-0.00 \\
0.33 \\
-0.32 \\
\end{array}$ & $\begin{array}{l}-2.72 \\
2.16 \\
-3.08 \\
-1.20 \\
-0.32 \\
-0.19 \\
-0.04 \\
-0.01 \\
-0.01 \\
1.23 \\
-1.13 \\
\end{array}$ & $\begin{array}{l}-0.94 \\
1.11 \\
-1.52 \\
-1.07 \\
-0.37 \\
0.59 \\
-0.05 \\
-0.54 \\
0.15 \\
0.29 \\
-1.49 \\
\end{array}$ & $\begin{array}{r}-2.75 \\
2.38 \\
-3.52 \\
-2.66 \\
-1.05 \\
1.65 \\
-0.13 \\
-0.97 \\
0.44 \\
0.80 \\
-2.99\end{array}$ \\
\hline 11. Intercept & -1.00 & -3.54 & 6.97 & 18.68 \\
\hline Observations & 1583 & & 1583 & \\
\hline F-stat/R-squared & 5.62 & & 0.32 & \\
\hline
\end{tabular}

Notes: Probability estimates refer to marginal probabilities. Items in [ ] refer to omitted reference category. 


\section{Appendix}

Table A1: Incidence of all non-voice related communication practices by workplaces with and without formal voice* (\%), 1998.

\begin{tabular}{|c|c|c|}
\hline \multirow[b]{2}{*}{ Communication Practice } & \multicolumn{2}{|c|}{ Formal voice present at workplace? } \\
\hline & No & Yes \\
\hline $\begin{array}{l}\text { 1. Management chain } \\
\text { 2. Suggestion schemes (narrow def. Re. Management consulting staff) } \\
\text { 3. Suggestion schemes (broader def. Including channels for suggesting } \\
\text { improvements to work methods) } \\
\text { 4. Newsletter } \\
\text { 5. European Works Council } \\
\text { 6. Any JCC (including those meeting less than once a month) } \\
\text { 7. Consultative committee above workplace level } \\
\text { 8. All two-way team briefings } \\
\text { 9. Two-way team briefings for an identifiable group of workers } \\
\text { 10. Other methods for consultation not elsewhere specified }\end{array}$ & $\begin{array}{c}12 \\
16 \\
2 \\
\\
2 \\
7(19)^{* *} \\
43 \\
8 \\
16\end{array}$ & $\begin{array}{c}37 \\
47 \\
6 \\
\\
23 \\
40(63)^{* * *} \\
89 \\
54 \\
14\end{array}$ \\
\hline
\end{tabular}

Notes: *Broad definition of "voice" is used.**Figures in parentheses use base=workplaces belonging to larger organisation. 
Figure 1: Frequency of HRM Scores For British Workplaces (10+employees), 1998

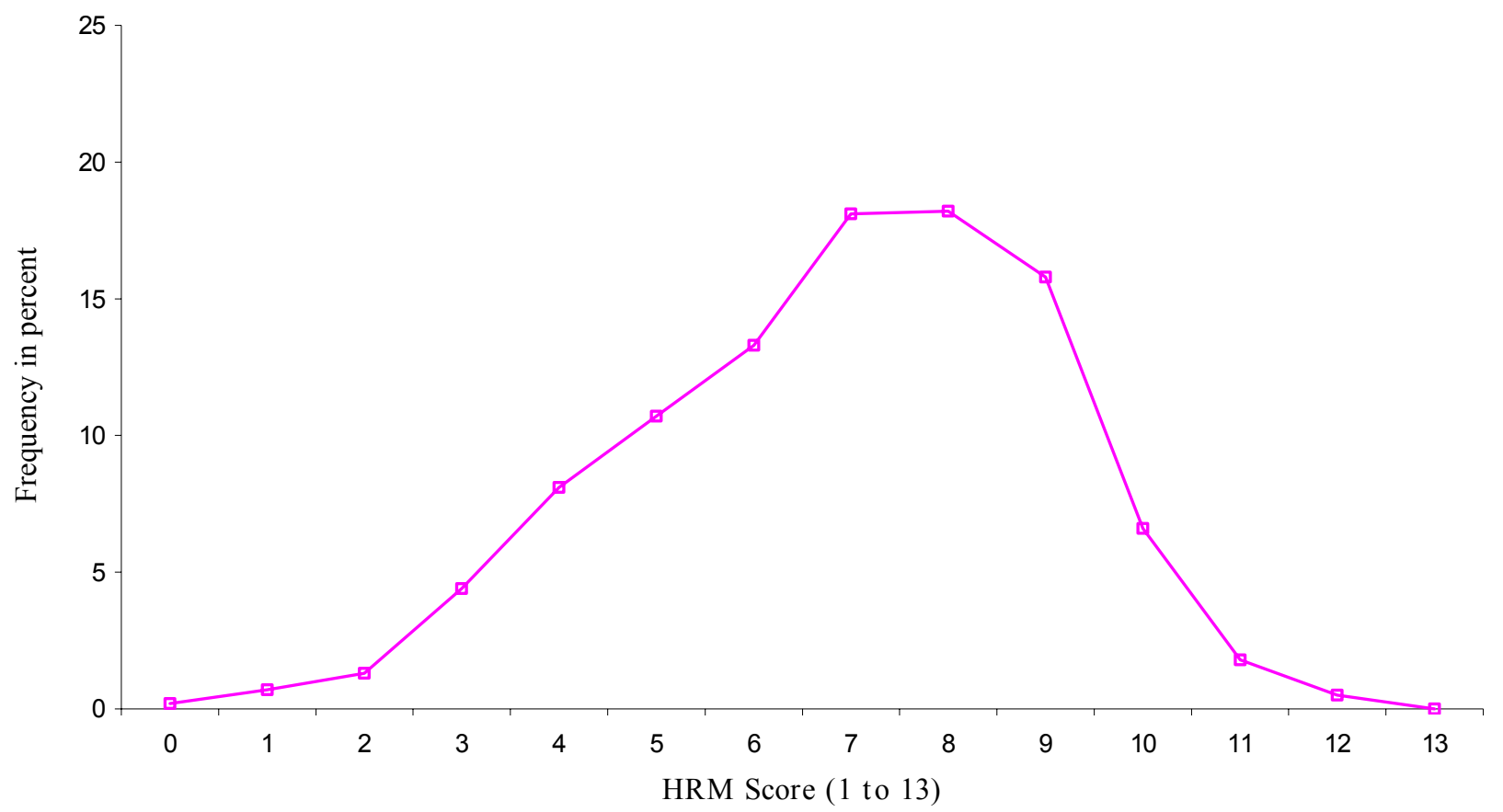


Figure 2:Use of Voice in Britain by Establishment Set-Up Date, Private Workplaces 1984-98

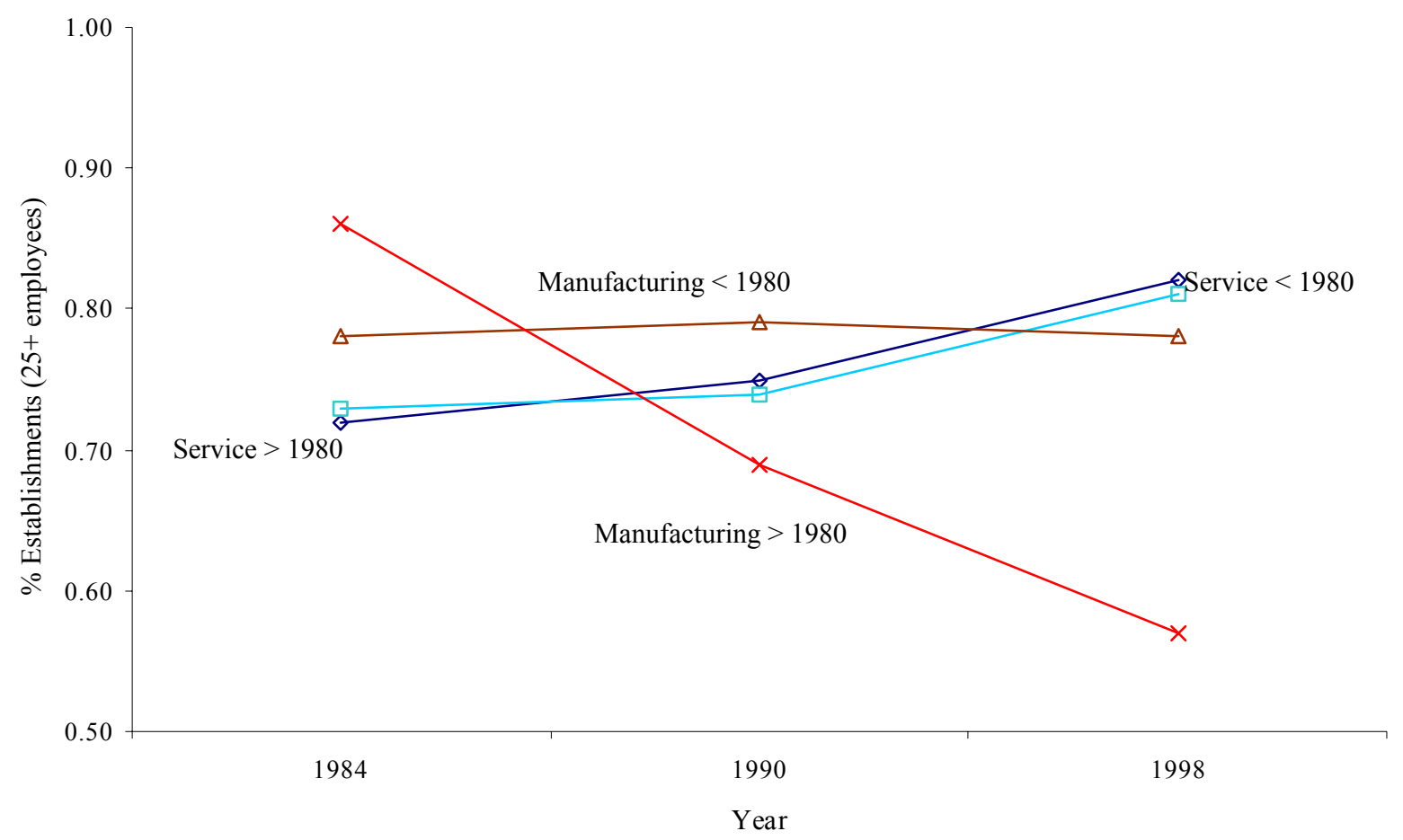


Figure 3: The Use of Voice in Britain by Type, All Workplaces 1984-98

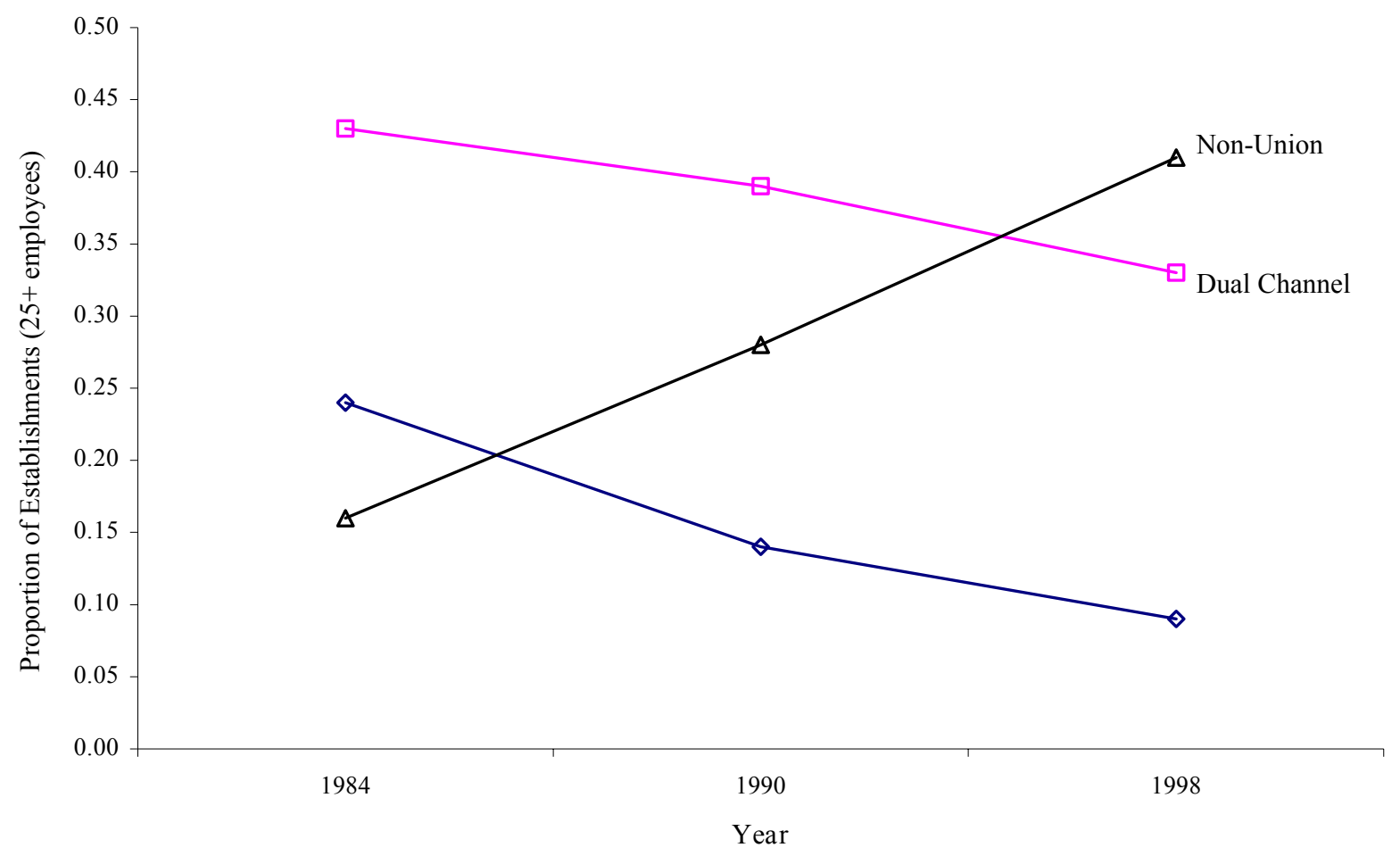


Figure 4: Use of Voice in Britain by Type and Set Up date, Private Manufacturing 1984-98

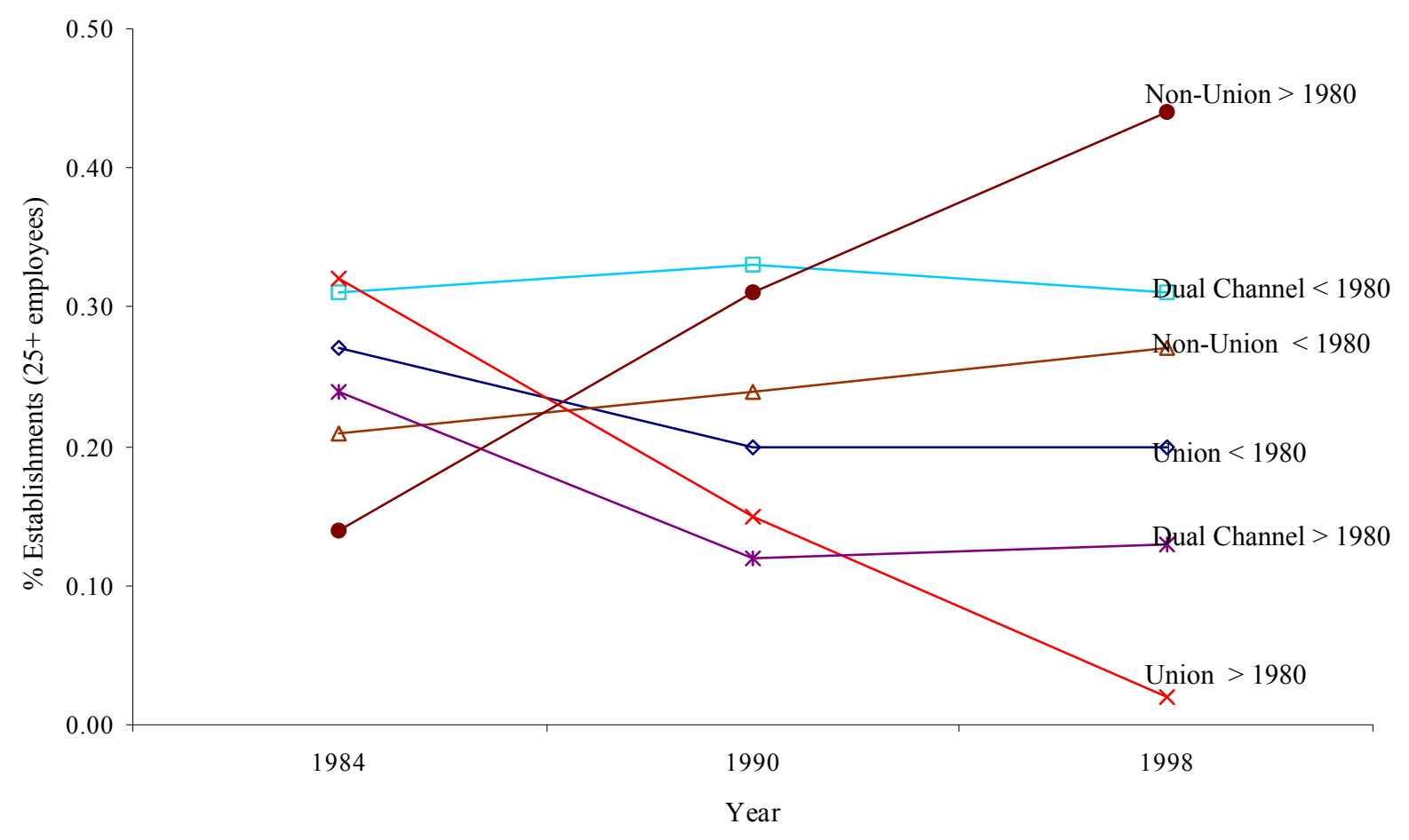


Figure 5: Frequency of HRM Scores by Voice For British Workplaces (10+employees), 1998

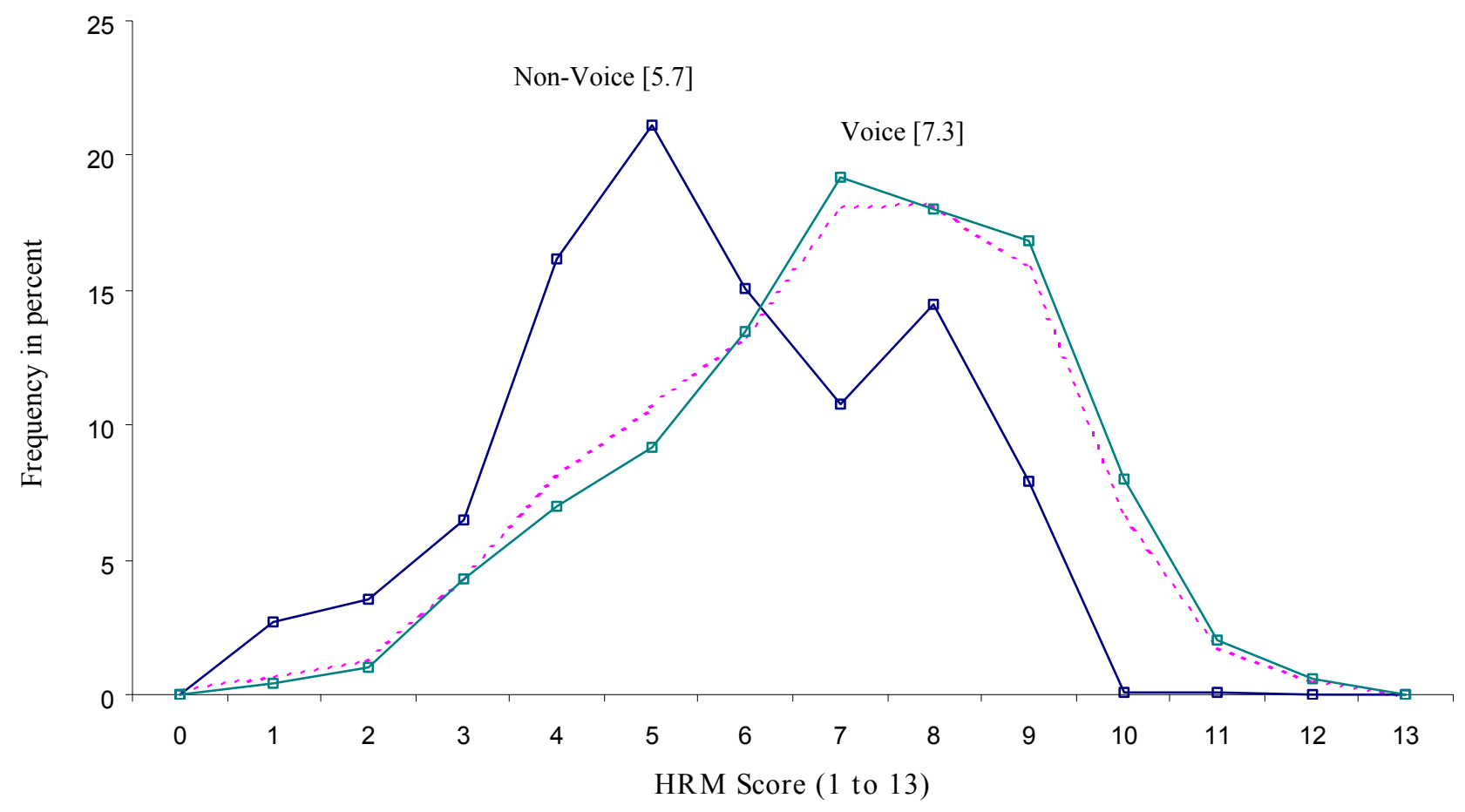


Figure 6: Frequency of HRM Scores by Type For British Workplaces (10+), 1998

Panel A: Workplaces With Union Voice Only [6.4]

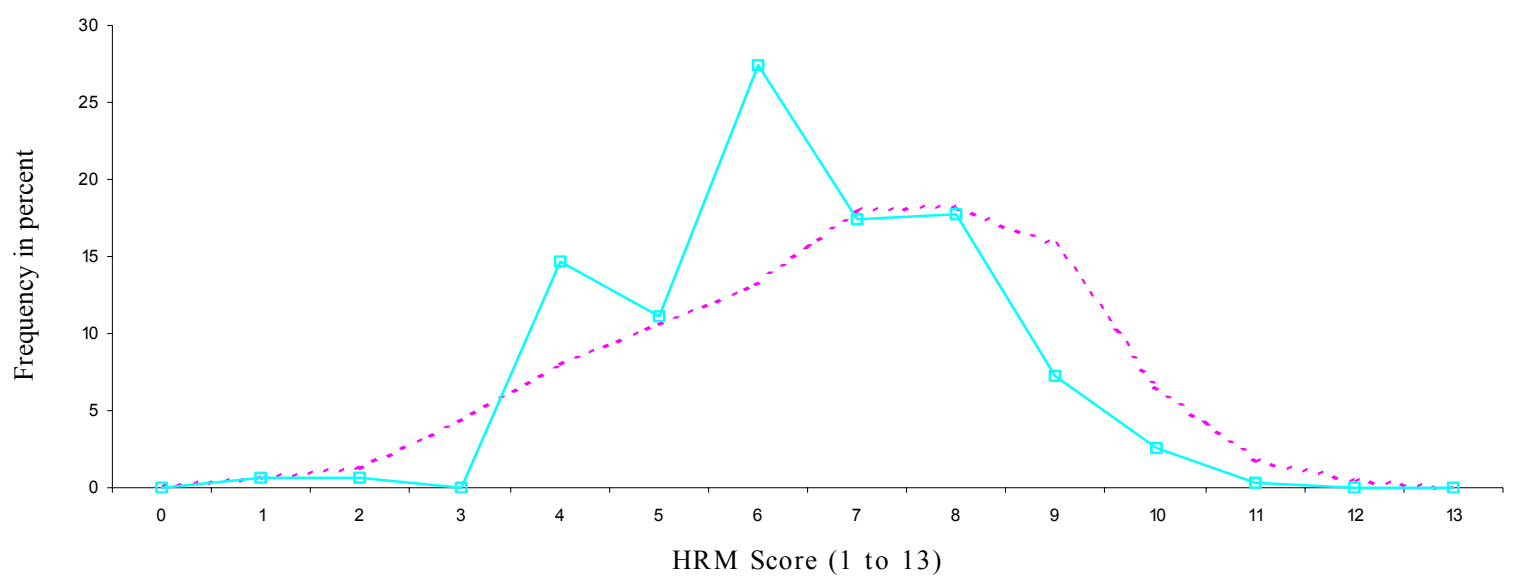

Panel B: Workplaces With Non-Union Voice Only [6.8]

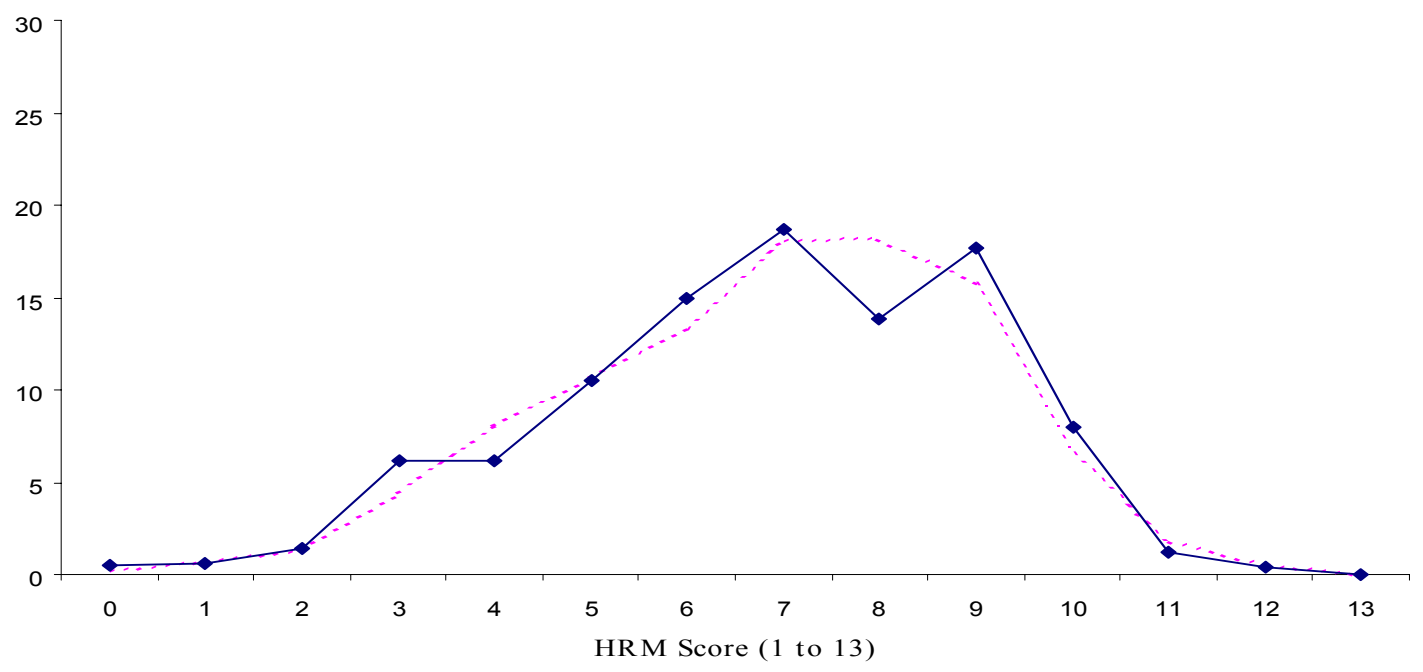


Panel C: Workplaces With Dual-Channel (Union + Non-Union) Voice [7.5]

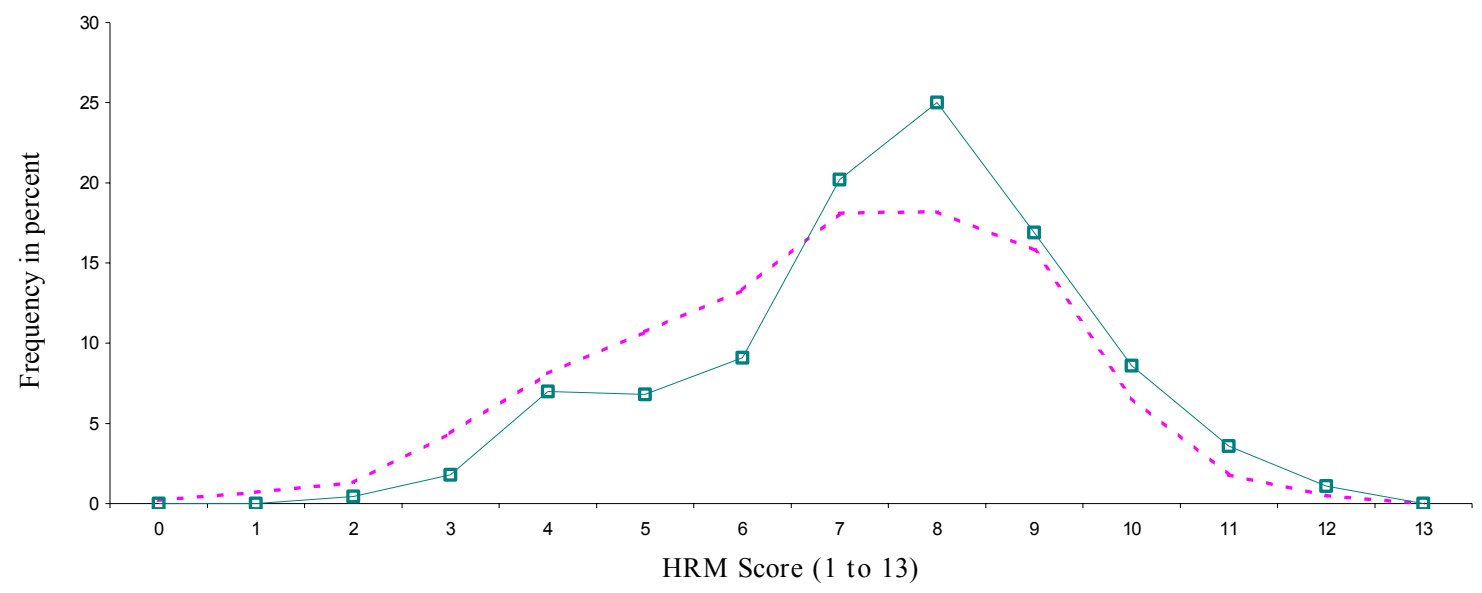




\section{CENTRE FOR ECONOMIC PERFORMANCE Recent Discussion Papers}

675 Nick Bloom

Mark Schankerman

John Van Reenen

674 Lorraine Dearden Howard Reed John Van Reenen

673 Giulia Faggio Stephen Nickell

672 Chiara Criscuolo Ralf Martin

671 Roberto Torrini

670 Silvia Ardagna Francesco Caselli Timothy Lane

669 Alejandro Cuñat Marco Maffezzoli

668 Francesco Caselli Silvana Tenreyro

667 Francesco Caselli

666 Gianluca Benigno Pierpaolo Benigno

665 Olmo Silva

664 Maarten Goos
Identifying Technology Spillovers and Product Market Rivalry

The Impact of Training on Productivity and Wages: Evidence from British Panel Data

Inactivity Among Prime Age Men in the UK

Multinationals and US Productivity Leadership: Evidence from Great Britain

Profit Share and Returns on Capital Stock in Italy: the Role of Privatisations Behind the Rise of the 1990s

Fiscal Discipline and the Cost of Public Debt Service: Some Estimates for OECD Countries

Can Comparative Advantage Explain the Growth of US Trade?

Is Poland the Next Spain?

Accounting for Cross-Country Income Differences

Designing Target Rules for International Monetary Policy Cooperation

Entrepreneurship: Can the Jack-of-All-Trades Attitude be Acquired?

Sinking the Blues: the Impact of Shop Closing Hours on Labor and Product Markets 
663 Christopher A. Pissarides Giovanna Vallanti

662 Philip R. Lane

Gian Maria Milesi-Ferretti

661 Alex Bryson Lorenzo Cappellari Claudio Lucifora

660 David Marsden Richard Belfield

659 Rachel Griffith Rupert Harrison John Van Reenen

658 Douglas Kruse Richard B. Freeman Joseph Blasi Robert Buchele Adria Scharf Loren Rodgers Chris Mackin

657 Christopher Crowe

656 James Banks Richard Disney

Alan Duncan John Van Reenen

655 Eran Yashiv

654 Hilary Steedman Sheila Stoney

653 Ralf Martin
Productivity Growth and Employment: Theory and Panel Estimates

Financial Globalization and Exchange Rates

Do Job Security Guarantees Work?

Unions, Performance-Related Pay and Procedural Justice: the Case of Classroom Teachers

How Special is the Special Relationship? Using the Impact of R\&D Spillovers on UK Firms As a Test of Technology Sourcing

Motivating Employee Owners in ESOP Firms:

Human Resource Policies and Company Performance
Inflation, Inequality and Social Conflict

The Internationalisation of Public Welfare Policy
The Self Selection of Migrant Workers Revisited

Disengagement 14-16: Context and Evidence

Globalisation, ICT and the Nitty Gritty of Plant Level Datasets

The Centre for Economic Performance Publications Unit Tel 02079557673 Fax $02079557595 \quad$ Email info@cep.lse.ac.uk Web site http://cep.Ise.ac.uk 